\title{
Environmentální výuka s ohledem na vnímání krajiny a její emocionální působení v kontextu dopravních staveb
}

\section{Kristýna Neubergová}

\author{
Envigogika 10 (4) - Př́padové studie/Case Studies
}

Publikováno/Published dne 29. 12. 2015

DOI: $\underline{10.14712 / 18023061.493}$

\begin{abstract}
Abstrakt
Příspěvek je zaměřen na problematiku výuky environmentálních předmětů na Českém vysokém učení technickém v Praze Fakultě dopravní (FD ČVUT). Protože každá dopravní stavba nemalou měrou ovlivňuje území, kterým prochází, je třeba, aby na okolní krajinu byl brán zřetel již při jejím samotném návrhu. Na FD ČVUT proto mají budoucí dopravní inženýři také předměty zaměřené na tuto oblast. Již od samotného počátku fungování FD ČVUT, to jest od akademického roku 1993/94, měli studenti kromě předmětů zaměřených na výuku čistě dopravních předmětů také předměty z environmentální oblasti, prvním z nich pak byl povinný předmět Tvorba a ochrana krajiny. $V$ příspěvku je zhodnocena výuka především s ohledem na její přesah do oblasti ovlivnění krajiny dopravními stavbami a dopravou vůbec. Jsou zde shrnuty jednotlivé environmentální předměty včetně jejich konkrétní náplně. Dále je $v$ př́spěvku zmíněna projektově orientovaná výuka a rozdělení bakalářských a diplomových prací na základě jejich tematického zaměření. $V$ dalším textu jsou pak diskutovány prínosy outdoorové výuky pro vysokoškolské studenty.
\end{abstract}

\section{Klíčová slova}

Environmentální výuka; outdoorová výuka; dopravní fakulta; dopravní stavby; krajina

\begin{abstract}
The paper is focused on teaching environmental subjects at the Faculty of Transportation Sciences at the Czech Technical University in Prague. Every transport construction affects the territory through which it passes and therefore it is necessary that the surrounding area has been taken into account already in the proposal itself. There are environmental courses at the Faculty of Transportation Sciences: the first (Landscape Protection) was opened in the academic year 1993/94, when the Faculty in Prague was established. The paper evaluates the course paying particular attention to the perception of landscape and its emotional impact in the context of transport structures. This contribution summarizes the various environmental subjects and their specific contents. Furthermore, the article looks at project-oriented teaching and the distribution of bachelor and masters theses based on their thematic focus. The text then discusses the benefits of outdoor lessons for students.
\end{abstract}

\section{Keywords}

Environmental education; Outdoor education; Faculty of Transportation Sciences; Road construction; Landscape 


\section{Dopravní stavby a krajina}

Problematika krajiny, jejího vývoje, působení na psychiku lidí i jejich zdraví je velmi aktuálním tématem. S okolním prostředím je konfrontován každý z nás. Je zajímavé, že na nevinný dotaz v rámci přednášky předmětu „Posuzování dopravních staveb", jak vlastně studenti vnímají prostředí kolem sebe, zda si ho vůbec uvědomují, panuje nejprve zaražené ticho. Teprve postupně se jednotliví studenti začínají osmělovat, a pokud je možné jejich odpovědi generalizovat, pak vnímají okolní prostředí především tehdy, pokud se něčím vymyká. Okolní přírodní krajinu na prázdninovém pobytu nebo naopak hlučné velkoměsto po př́jezdu zpět. V běžném každodenním životě si však okolní prostředí uvědomujeme relativně málo a proplouváme všedními dny, aniž bychom se zastavili, rozhlédli a uvědomili si, kde vlastně jsme.

Také dopravní stavby v krajině, at' už silniční nebo železniční, vnímáme tak nějak samozřejmě. Teprve pokud se chystá nová stavba, která má do území vstoupit, začneme se rozhlížet a přemýšlet o tom, jak může okolní prostředí ovlivnit, zda negativně, jak je to většinou chápáno i prezentováno, či pozitivně. O tom, že ovlivnění krajiny dopravní stavbou nemusí být nutně jen negativní, svědčí i fakt, že mnohá údolí se stala zajímavá např́klad až poté, co zde byl vybudován most.

Dopady dopravy na životní prostředí a okolní krajinu jsou často zmiňovány také v řadě médií, mnohdy je však s pojmy doprava, životní prostředí nebo krajina zacházeno velmi volně. Proto je třeba si je nejdřive co nejpřesněji vymezit a definovat. Mezi nejčastěji užívané termíny patří sousloví životní prostředí, pod kterým ale bývá velmi často chápána především jeho přirodní složka. Přitom již v roce 1967 definoval norský profesor S. Wik životní prostředí jako „tu část světa, s níž je člověk ve vzájemném působení (interakci), tj. již používá, ovlivňuje a které se přizpůsobuje" (Rohon, 1991). Tato definice, která byla přijata organizací UNESCO, se stala jednou z nejpoužívanějších a byla také převzata do řady dalších oficiálních materiálů, včetně českých.

Definic krajiny existuje celá řada v závislosti na úhlu pohledu, s nímž na danou problematiku nahlížíme. Podle krajinných ekologů je krajina "heterogenní území tvořené shlukem vzájemně se ovlivňujících ekosystémů, které se stále opakují, rozsah je většinou několik kilometrů v průměru a větší" (Forman a Godron, 1993). Česká legislativa definuje krajinu jako „část zemského povrchu s charakteristickým reliéfem, tvořenou souborem funkčně propojených ekosystémů a civilizačními prvky" (Česká republika, 1992, § 3).

Také doprava má samozřejmě svou definici a na akademické půdě jsou vedeny spory o to, zda je či není doprava vědním oborem. Doprava je chápána jako „soubor činností, jimiž se uskutečňuje pohyb dopravních prostředků po dopravních cestách a přemistování osob a věcí dopravními prostředky nebo dopravními zařízeními" (Kočárková a kol., 2004).

\section{Pohled na vnímání krajiny v rámci environmentálních předmětů}

Přijmeme-li fakt, že dopravní stavby jen těžko zrušíme, je třeba věnovat pozornost jejich působení na prostředí a okolní krajinu. Protože dopravní inženýři, projektanti i stavitelé dopravních staveb jsou v první linii, je nezbytné jejich odpovídající vzdělání. Je potřeba, aby si kromě základních znalostí a dovedností v oblasti navrhování i provozu dopravních cest odnesli ze školy také znalosti v oblasti environmentální a krajinářské. Je potěšující, že mnozí z nich si tuto nutnost uvědomují a prochází tak všemi nejen povinnými, ale také povinně volitelnými environmentálními předměty, jejichž výčet a zastoupení v rámci jednotlivých stupňů studia je shrnut pro konkrétní případ FD ČVUT v tabulce číslo 1. 
Tabulka 1. Zastoupení environmentálních předmětů na FD ČVUT

\begin{tabular}{|l|l|}
\hline Bakalářský stupeň studia & Magisterský stupeň studia \\
\hline Aplikovaná ekologie & Doprava a životní prostředí \\
\hline Posuzování dopravních staveb & Krajinná ekologie \\
\hline & Udržitelná doprava \\
\hline
\end{tabular}

Postupem doby fungování FD ČVUT docházelo $v$ rámci akreditací a reakreditací studijních programů také ke změnám vyučovaných předmětů. $K$ největším změnám pak došlo po přechodu na strukturované studium, kdy se studium rozdělilo do dvou stupňů - na bakalářský a magisterský. $V$ rámci bakalářského studia mají studenti také povinně volitelné předměty Aplikovaná ekologie a Posuzování dopravních staveb. $V$ předmětu Aplikovaná ekologie (dřive Ekologie) se studenti seznamují s environmentální problematikou více $v$ obecné rovině, kdy si prohlubují své znalosti z nižších stupňů vzdělání. Důraz je při výuce kladen také na postavení dopravy a dopravních staveb $v$ rámci dané tématiky.

V své semestrální práci pak studenti popisují a hodnotí konkrétní dopravní stavbu ve vztahu k soustavě chráněných ploch NATURA 2000. Při jejím zpracování by však neměli vystačit jen s načtenými informacemi, úkolem také je vyrazit do terénu a konkrétní lokalitu si prohlédnout na vlastní oči, nafotit a utvořit si vlastní představu. To je velmi důležité především na pozadí řady mediálních kauz, kdy je potřeba, aby si studenti utvořili vlastní názor a nepodléhali povrchním informacím z médií, které jsou mnohdy tendenční a povrchní.

Předmět Posuzování dopravních staveb je, jak název napovídá, zaměřen na problematiku posuzování vlivů dopravních staveb. Zde se studenti seznamují s procesem EIA a jeho jednotlivými fázemi a dále pak s metodami multikriteriálního hodnocení, rizikové analýzy či analýzy SWOT. Jednotlivé metody jsou pro větší názornost demonstrovány na konkrétních dopravních stavbách, u kterých byly aplikovány. Dále se zde studenti seznamuji s dalšími krajinářskými metodami, metodikou hodnocení průchodnosti území a především s metodami hodnocení krajinného rázu (Löw a Míchal, 2003).

Jak již bylo řečeno úvodem, každá dopravní stavba vnáší do krajiny nevratné změny. Tyto změny jsou většinou chápány jako negativní, i když tomu tak nutně nemusí být vždy. Právě k posouzení míry ovlivnění krajiny, nejen dopravní stavbou, slouží metodika posuzování vlivů na krajinný ráz. $V$ rámci přednášek je problematika posouzení vlivů na krajinný ráz demonstrována na řadě praktických příkladů i známých kauz. Studenti se pak sami snaží vypracovat, byt' ve zjednodušené formě, zhodnocení vybrané dopravní stavby. Zajímavá je poté diskuse nad jednotlivými posudky, kdy jsou zřejmé rozdíly $\vee$ pohledu na konkrétní stavbu.

$\checkmark$ rámci studia magisterského mají studenti povinný předmět Doprava a životní prostředí, kdy jsou podrobně rozebírány jednotlivé negativní vlivy dopravy a možnosti jejich eliminace. $V$ rámci předmětu se studenti také seznamují s problematikou hluku, a aby jejich znalosti nebyly pouze teoretické, vyrážejí také s hlukoměrem do terénu. Probíhá tak konkrétní měření dopravního hluku v exponovaných pražských lokalitách. Studenti naměřená data následně analyzují a lépe tak do celé složité problematiky pronikají.

Dále maji studenti FD ČVUT v magisterském stupni studia možnost rozšiřovat své environmentální znalosti $v$ rámci volitelného předmětu Krajinná ekologie, který je věnován 
právě především dopadům dopravy na krajinu. Samozřejmě jsou v úvodních přednáškách probírána teoretická témata a část přednášek je věnován např́klad problematice povodní, obnově a rekultivacím a také dalším jevům s krajinou úzce souvisejících. Nicméně většina času je věnována především dopravě, vedení dopravních staveb územím, vlivu silničních i železničních staveb na rozmístění sídel a také vztahu mezi dopravou a suburbanizací. Tedy fenoménem posledních let, kdy se doprava stává $v$ mnoha prípadech iniciátorem další výstavby. Tato výstavba, at už komerční nebo rezidenční pak zpětně indukuje potřebu další dopravní obslužnosti a vzniká tak vlastně uzavřený kruh. Pozornost je pak věnována také tolik diskutované problematice výsadby zeleně podél dopravních cest. Zde se naše společnost pohybuje od extrému k extrému a kde je potřeba jasně stanovit pravidla tak, aby naše krajina, do které aleje a stromořadí neodmyslitelně patří, nebyla o tento př́rodní prvek ochuzena a zároveň aby byla co nejméně ovlivněna bezpečnost, resp. nebezpečnost dopravy.

Výuka na FD ČVUT je specifická svou projektově orientovanou výukou, která spočívá $v$ tom, že si studenti zvolí na základě svého zájmu projekt s konkrétním zaměřením, v jehož rámci zpracovávají semestrální, bakalářské a diplomové práce a dále se pak profilují v dané oblasti. Jednou z možných oblastí profilace je také problematika dopravy a životního prostředí. Již v roce 1999 byl otevřen projekt s názvem Vztah dopravy ke krajině, který byl posléze přejmenován obecněji na Dopravu a životní prostředí. Za dobu působení projektu úspěšně dokončilo studium více než 30 studentů. Témata bakalářských i diplomových prací jsou různá a závisí především na zájmu a př́stupu studenta. Obecně se dají rozdělit do několika větších skupin, a to na oblast dopravního hluku, problematiku emisí a imisí znečištujujicích látek $v$ ovzduší a jejich modelování, oblast fragmentace krajiny a řešení bariérového efektu a posuzování dopravních staveb. Shrnutí témat včetně procentuálního zastoupení jednotlivých prací je uvedeno $v$ tabulce číslo 2 .

\section{Tabulka 2. Zastoupení témat bakalářských a diplomových prací v rámci environmentálně zaměřeného projektu na FD ČVUT.}

\begin{tabular}{|l|l|l|l|}
\hline Téma hluku & $\begin{array}{l}\text { Téma posuzování } \\
\text { dopravních staveb }\end{array}$ & $\begin{array}{l}\text { Téma fragmentace } \\
\text { a bariérového } \\
\text { efektu }\end{array}$ & $\begin{array}{l}\text { Ostatní témata (zne- } \\
\text { čištění ovzduší, sub- } \\
\text { urbanizace...) }\end{array}$ \\
\hline $58 \%$ & $22 \%$ & $10 \%$ & $10 \%$ \\
\hline
\end{tabular}

Vlastní tvorba bakalářských a diplomových prací vyžaduje od studentů kromě rešeršní činnosti a uplatnění nastudovaných znalostí také práci v terénu. $U$ prací zaměřených na oblast zatížení prostředí hlukem z dopravy provádí studenti řadu měření zvukovým analyzátorem. Další průzkumy se pak týkají především určení intenzit dopravy a rekognoskace terénu. Ke krajinářství mají nejblíže témata vztahující se $\mathrm{k}$ hodnocení průchodnosti území a posouzení fragmentace území vybranou dopravní stavbou. Studenti např́klad prováděli konkrétní měření hluku i osvětlení na vybraných ekoduktech nebo posuzovali vybraný dálniční či železniční úsek z hlediska průchodnosti pro volně žijící živočichy. Zejména při těchto pracích a také při posuzování variant vedení dopravních tras se studenti seznamují s prací v terénu, a získávají tak neocenitelné praktické zkušenosti a také vlastní náhled na spolupưsobení dopravní stavby a okolního prostředí. 


\section{Závěr, shrnutí}

Nejen pro žáky základních či středních škol, také pro studenty škol vysokých je outdoorová výuka velmi důležitá. $V$ dnešní době, kdy je velmi snadné a pohodlné vyhledat celou řadu informací, byt́ se vážným problémem stává určení jejich relevantnosti, je nezbytné získat informace také jinou formou než hledáním v síti internetu. Informace i údaje, které studenti získají sami, které si mají možnost „osahat" v terénu, naměřit, pochopit, pak tvoří nezbytnou základnu jejich odbornosti. Práce v terénu vede $\mathrm{k}$ samostatné práci (míněno z pohledu spolupráce jednotlivých členů týmu, nikoli pohledu čistě individualistického) a ke schopnosti zamyslet se nad problémem a s ohledem na vlastní názor formulovat závěry v rámci celého týmu.

\section{Literatura}

- ČEESKÁ REPUBLIKA. Zákon č.114/92 Sb., o ochraně přírody a krajiny. Sbírka zákonů. 1992. Dostupné také z: http://www.mzp.cz/www/platnalegislativa.nsf/d79c09c54250df0dc1256e8900296e32/58170589E7DC0591C125654B004 E91C1/\$file/Z\%20114_1992.pdf

- FORMAN, Richard T. T. a Michel GODRON. Krajinná ekologie. Praha: Academia, 1993. ISBN 80-200-0464-5.

- KOČÁRKOVÁ, Dagmar, Petr SLABÝ, Josef KOCOUREK a Martin JACURA. Základy dopravního inženýrství. Praha: ČVUT, 2004. ISBN 80-01-03022-9.

- LŐW, Jiří a Igor MÍCHAL. Krajinný ráz. Kostelec nad Černými lesy: ČZU, 2003. ISBN 80-86386-27-9.

- ROHON, Pavel. Základy životního prostředí. Praha: ČVUT, 1991. ISBN 80-0100528-3. 